\title{
Evaluation of thymic lymphocyte loss of broiler using Digital Analysis of the Lymphoid Depletion System (ADDL) ${ }^{1}$
}

\author{
Daiane Carvalho², Lucas Brunelli de Moraes ${ }^{3}$, Gabriela Zottis Chitolina², Juliana \\ Inês Herpich ${ }^{2}$, Fernando Santos Osório ${ }^{4}$, Luiz Cesar Bello Fallavena ${ }^{5}$, Hamilton \\ Luiz de Souza Moraes ${ }^{2}$ and Carlos Tadeu Pippi Salle ${ }^{2 *}$
}

\begin{abstract}
Carvalho D., Moraes L.B., Chitolina G.Z., Herpich J.I., Osório F.S., Fallavena L.C.B., Moraes H.L.S. \& Salle C.T.P. 2016. Evaluation of thymic lymphocyte loss of broiler using Digital Analysis of the Lymphoid Depletion System (ADDL). Pesquisa Veterinária Brasileira 36(7):652-656. Centro de Diagnóstico e Pesquisa em Patologia Aviária, Faculdade de Veterinária, Universidade Federal do Rio Grande do Sul, Av. Bento Gonçalves 8824, Porto Alegre, RS 90540-000, Brazil. E-mail: tadsalle@gmail.com

The thymus is a lymphoid organ and usually evaluated for the degree of lymphocyte loss with subjective histological techniques. This study aimed to adapt and to apply of the digital analysis of the lymphoid depletion system (ADDL) in the thymus in order to obtain a more accurate analysis. Glucocorticoid was used to induce immunosuppression in 55 broilers at 21 days of age; other 15 broilers were the control group. After euthanasia of the broilers, postmortem examination was made. Both thymic chains were collected and six lobes were selected for histological examination of the degree of lymphocyte depletion (scores 1 to 5) and for submission to all stages of processing by the ADDL system. The artificial constructed neural networks (ANN) obtained $94.03 \%$ of correct classifications. In conclusion, it was possible to adopt objective criteria to evaluate thymic lymphoid depletion with the ADDL system.
\end{abstract}

INDEX TERMS: Poultry, cellular immunity, lymphoid depletion, image analysis, artificial neural networks.

RESUMO.- [Avaliação de perda de linfócitos do timo em frangos usando análise digital do sistema de depleção linfóide (ADDL).] 0 timo é um órgão linfóide, que é normalmente avaliado para o grau de perda de linfócitos a partir de técnicas histológicas subjetivas. Este trabalho teve como objetivo a adaptação e aplicação do sistema de análise digital de depleção linfóide (ADDL) para o timo, a fim

\footnotetext{
${ }^{1}$ Received on June 30, 2015.

Accepted for publication on April 26, 2016.

${ }^{2}$ Centro de Diagnóstico e Pesquisas em Patologia Aviária (CDPA), Universidade Federal do Rio Grande do Sul (UFRGS), Av. Bento Gonçalves 8824, Porto Alegre, RS 91540-000, Brazil. *Corresponding author: tadsalle@ gmail.com

${ }^{3}$ Instituto de Pesquisa Veterinária Desidério Finamor (IPVDF), Fundação Estadual de Pesquisa Agropecuária (Fepagro), Estrada Municipal do Conde 6000, Eldorado do Sul, RS 92990-000, Brazil.

${ }^{4}$ Instituto de Ciências de Matemática e Computação (ICMC), Universidade de São Paulo (USP), Av. Trabalhador São-Carlense 400, Cx. Postal 668, São Carlos, SP 13560-970, Brazil.

${ }^{5}$ Universidade Luterana do Brasil (Ulbra), Rua Miguel Tostes 101, Canoas, RS 92420-280, Brazil.
}

de tornar sua análise mais acurada. Glicocorticóides foram utilizados a fim de induzir imunossupressão em 55 aves de 21 dias de idade. Outras 15 aves formaram o grupo controle. Posteriormente, para cada um dos aves, realizou-se a eutanásia e necropsia. Ambas as cadeias do timo foram coletadas e foram selecionadas seis lóbulos para processamento histológico, análise quanto ao grau de depleção linfocitária (escores de 1-5) e submissão a todas as fases do processamento pelo sistema ADDL. Observou-se que a rede neural artificial (RNA) construída obteve 94,03\% de classificações corretas. Em conclusão, foi possível adotar critérios objetivos para avaliar a depleção linfóide tímica utilizando o sistema ADDL.

TERMOS DE INDEXAÇÃO: Aves, imunidade celular, depleção linfóide, análise de imagem, redes neurais artificiais.

\section{INTRODUCTION}

The intense technification of poultry farming makes the density increase, what leads to a higher concern on animal health. Among the most important diseases are the ones 
that directly affect the immune system, turning birds susceptible to opportunistic agents. Thymus is one of the most attacked organs by immunosupressed diseases being the histological evaluation of the tissue injury performed widely variable. Therefore, there is not a "gold standard" to quantify the lymphocyte loss.

Sharma et al. (1993) created lesion scores for the thymus varying from 1 to 4 , using the terms "mild", "moderated" and "severe" in order to quantify the lymphocyte loss. Smyth et al. (2009) evaluated thymic lesions by the nucleus size increase in $\mathrm{T}$ lymphocytes, pale color of the chromatin, intranuclear inclusions, cortical lymphocytary depletion and the occurrence of structures that were similar to apoptotic bodies. Hadipour et al. (2011) used only the presence/ absence criteria of the lymphoid tissue necrosis and depletion in the thymic medulla. Hussain et al. (2012) analyzed the thymus after establishing 5 scores based on the cortical necrosis and atrophy: $0=$ no lesion; $1=$ mild multifocal necrosis; 2 = moderate multifocal necrosis or diffuse mild cortical atrophy; 3 = moderate diffuse cortical atrophy; $4=$ severe diffuse cortical atrophy. In order to improve the evaluation of the lymphocytary loss of the thymus, researchers such as Van Santen et al. (2004) and Toro et al. (2009), used the image analysis to measure the scope of the thymic lobe and calculate the cortical medullar relation.

This wide methodological variation observed on the study of the thymus is the result of a lack of clear and objective criteria. Such criteria is essential in order to provide support on based decision making, allowing ones to establish the degree of the lymphoid tissue. In addition there is the lack of repeatability and reproducibility of the applied methods. Such characteristics are indispensable regarding a laboratorial tool so spread as the histopathology.

Moraes et al. (2010) proposed a new methodology that reduces considerably the subjectivity to establish the lymphocytary loss of the cloacal bursa through a system called Digital Analyses of the Lymphoid Depletion (ADDL - Avaliação Digital da Depleção Linfocitária). The ADDL is based on the use of image analyses and artificial intelligence, producing a more accurate method to quantify the lesion. The aimed of this work was the adaptation and application of ADDL system to broiler thymus samples in order to make the evaluation of lymphoid more objective.

\section{MATERIALS AND METHODS}

Submission to the ethics committee. The research Project is registered at the Animal Care Committee from the Veterinary Research Institute Desidério Finamor (CEUA-IPVDF), under the protocol 21/2012.

Birds. Seventy chicks one day old were used. The birds were housed in an acclimatized room, with artificial light and distribu- ted into metal brooder cages. The animals were fed with water and ration "ad libitum" throughout the experimental period.

Experimental design. When the chicks were 21 days old (considered day zero), two groups were formed, control (15 birds) and treated one (55 birds). The treated group received intramuscular dexamethasone $(5 \mathrm{mg} / \mathrm{kg}$ - DEXIUM at a concentration of $2 \mathrm{mg} / \mathrm{ml}$ ), according to the modified protocol from Kong et al. (2002).

In order to get different degrees of lymphoid depletion, the birds were treated on day zero, day one, day three and day five. Between day zero and day four twenty five birds were sacrificed every 24 hours - one bird from control group and four birds from treated group. With bird had its sweetbreads collected. After the day six, five samples were taken every eight hours from five birds of the treated group and one bird from the control. The last sampling was done on day 13 (8 days after the last dexamethasone administration) to obtain thymus with intermediate scores of lymphocyte depletion. Table 1 shows the treatment protocol between day 0 and 13. During the period of housing, three animals belonging to the treated group had died for reasons external to the experiment, so, they were excluded of this study.

Euthanasia of birds and sampling the thymus. The birds were anesthetized with the combination of an intramuscular single dose of $2 \%$ Ketamine $20 \mathrm{mg} / \mathrm{kg}$ and $10 \%$ Xylasine $3 \mathrm{mg} / \mathrm{kg}$ (Tranquilim et al. 2007). After, they were euthanatized through electrocution (110V). Immediately after the sacrifice, birds were necropsied and both thymic chains were collected and placed into bottles with $10 \%$ buffered formalin solution.

Preparation of histological sections. After 24 hour fixing, three lobes were selected in each of the thymic chains (six lobes/ broiler). Based on the criteria of choice the one that had total separation with the adjacent lobes. The lobes were cleaved, identified and processed until the inclusion into paraffin. Cuts were obtained $(5 \mu \mathrm{m})$ and stained with hematoxylin and eosin according to Luna (1968).

Slides of histological evaluation. First, um lobe per sampling was selected in order to obtain five scores related to the lymphoid depletion. These 13 slides had a degree of lymphocytary tissue damage determined by two evaluators through the subjective conventional method (optic), where the optic score (OS) 1 represented the absence of depletion and the score 5, the maximum lymphocytes loss. These slides were later used as a pattern to classify the others lobes.

Two histopathologists evaluated the two other slides blindly and at random. The final depletion score of every broiler was obtained by using the mode of the scores of the six thymic lobes from both evaluators.

Image capture. Each of the 402 thymic lobes was divided into eight parts (octants), and numbered clockwise from 1 to 8 . Digital photomicrographs (Fig.1) were obtained from each octant.

The pictures were taken with an OLYMPUS ${ }^{\circledR} \mathrm{C}-7070$ camera, coupled to trinocular OLYMPUS ${ }^{\circledR}$ CX40 microscopy, with $200 \mathrm{x}$ magnification, TIFF format and 3072x2304 resolution. Particular care was taken in order to get into the octant with a defocusing microscopy avoiding areas with artifacts. The image should comprise both medullar and cortical portions.

Table 1. Number (n) of birds for the sampling of the thymus between the days 0 and 13

\begin{tabular}{|c|c|c|c|c|c|c|c|c|c|c|c|c|c|}
\hline $\begin{array}{l}\text { Day } \\
\text { (sampling) }\end{array}$ & Day 0 & Day 1 & $\begin{array}{c}\text { Day } 2 \\
\text { (3) }\end{array}$ & $\begin{array}{c}\text { Day } 3 \\
(4)\end{array}$ & $\begin{array}{c}\text { Day } 4 \\
(5)\end{array}$ & $\begin{array}{c}\text { Day } 5 \\
(6)\end{array}$ & $\begin{array}{c}\text { Day } 6 \\
8 \mathrm{~h} \\
(7)\end{array}$ & $\begin{array}{c}\text { Day } 6 \\
16 \mathrm{~h} \\
(8)\end{array}$ & $\begin{array}{c}\text { Day } 6 \\
24 \mathrm{~h} \\
(9)\end{array}$ & $\begin{array}{c}\text { Day } 7 \\
32 \mathrm{~h} \\
(10)\end{array}$ & $\begin{array}{c}\text { Day } 7 \\
40 \mathrm{~h} \\
(11)\end{array}$ & Day & \\
\hline Group & $\mathrm{C} T$ & $\overline{\mathrm{C} \quad \mathrm{T}}$ & $\mathrm{C} \mathrm{T}$ & $\overline{\mathrm{C} \mathrm{T}}$ & $\mathrm{C} \mathrm{T}$ & $\mathrm{C} \mathrm{T}$ & $\mathrm{C} \mathrm{T}$ & $\mathrm{C} \mathrm{T}$ & $\mathrm{C} \mathrm{T}$ & $\mathrm{C} \mathrm{T}$ & $\overline{\mathrm{C} \quad \mathrm{T}}$ & $\mathrm{C}$ & $\mathrm{T}$ \\
\hline $\mathrm{Nr}$ of birds euthanized & 14 & 14 & 14 & 14 & 14 & 11 & 15 & 15 & 15 & 15 & 15 & 4 & 6 \\
\hline
\end{tabular}




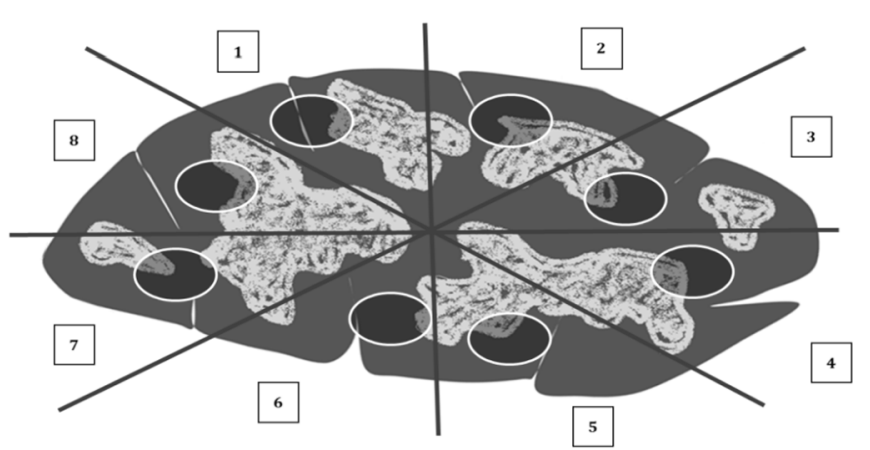

Fig.1. Illustrative image of the thymic lobe divided into eight sections that were selected for photomicrography.

Image analyses. The images were processed according established by Moraes et al. (2010) (Fig.2). It was done with the software Matlab ${ }^{\circledR} 6.5$ - Mathworks. Therefore the images were converted into 256 shades of gray scale and the selection in the area of interest was carried out.

After, there was their segmentation and the histogram characteristics were attained. At the end the values presented by the histogram were exported to a Microsoft excel table to calculate the Right area (RA), Left Area (LA), Midpoint Area (MA), Higher Point (HP) and Major Index (MI) (Fig.3).

Artificial neural networks (ANN). ANNs were generated with the items of the histogram to classify (Neuroshell ${ }^{\circledR}$ Classifier) and recognize the images in the distinct optical scores of the lymphoid depletion. The values of RA, LA, MP, HP and MI were given as input variables. The digital score (DS) was obtained as output variable characterizing the lymphoid loss. The final optical score was used for network training which was also useful for the comparison with the DS.

\section{RESULTS}

Establishment of lymphocyte depletion through OS per thymic lobe and per bird

It was possible to establish 5 scores related to the lymphocyte loss through the histological analyses of the thymic lobes.as shown in Table 2.

\section{OS of the thymus during 13 days treatment with Dexa- methasone}

According to the graphics of the Figure 4, from day 0 to 4 the scores of lymphocyte loss varied between 1 and 3 , for both the control and treated group. From the treatment performed on day 5 the depletion degree was higher and there were birds with score of thymus between 4 and 5 . There was evidence of the recovery of thymus in the collection carried out on day 13 once the score of the treated group decreased to 2 . The scored varied between 1 and 2 in the birds of the control group on day 13.

\section{Artificial neural networks}

Table 3 represents the results of classification of digital thymic scores from the use of the ANNs. The results correspond to the values obtained per bird.

The results observed, with the development of this network showed correct percentage of classification over $95 \%$ for all categories. As for the predictive positive value (PPV) it was observed that except the DS-1 and the DS 5, the others obtained values between 80 and $95 \%$.

The ANN produced $94.03 \%$ of correct classification. Only $5,97 \%$ of the samples were allocated in different DSs but all of them with scores immediately higher or lower.

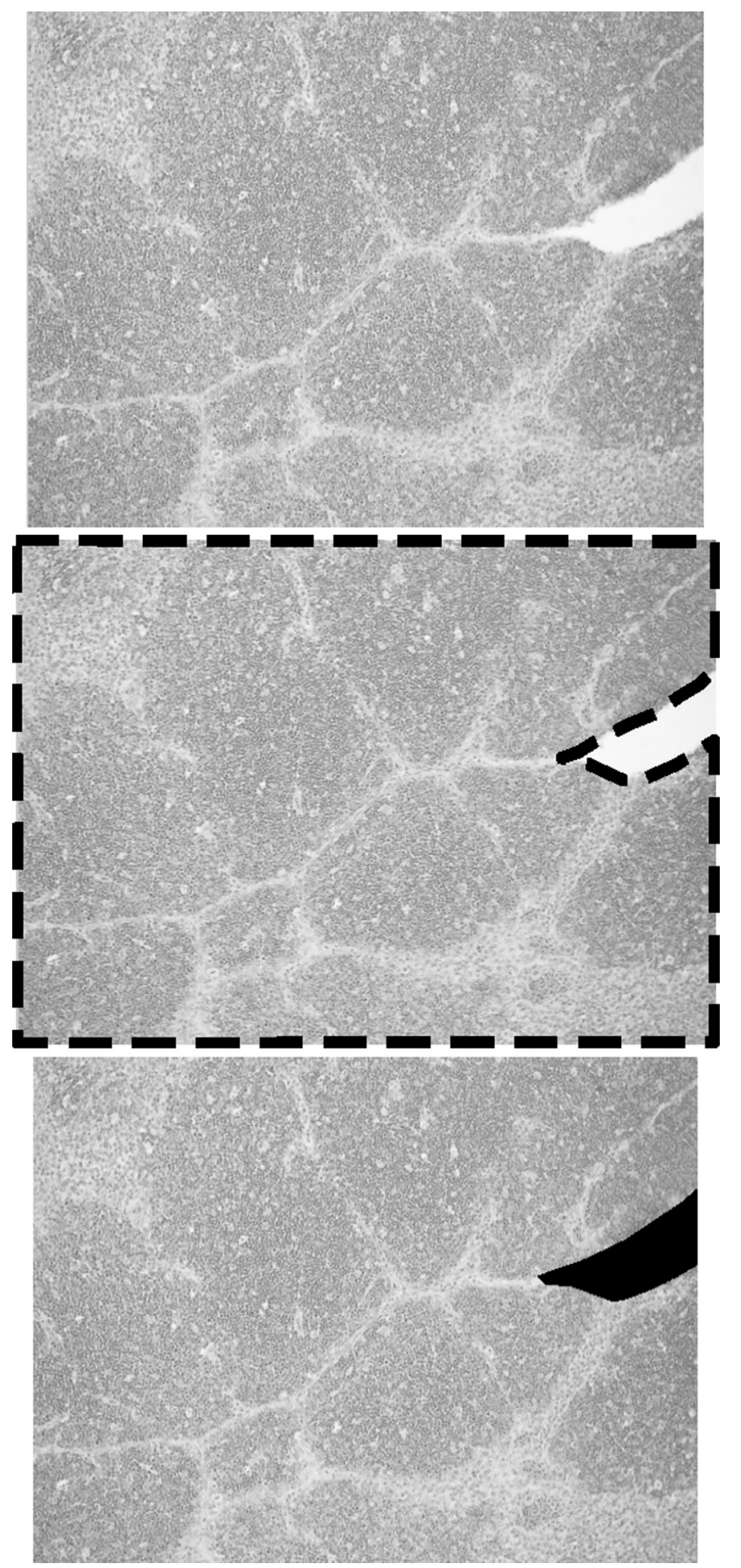

Fig.2. (A) Photomicrographs obtained from one of the eight sections of the thymic lobe and converted into the gray scale software Matlab ${ }^{\circledR} 6.5$ - Mathworks. (B) Interest area selection of one section of the thymic lobe - software Matlab ${ }^{\circledR} 6.5$ - Mathworks. (C) Segmentation of the selected one-software Matlab $^{\circledR} 6.5$ - Mathworks. 


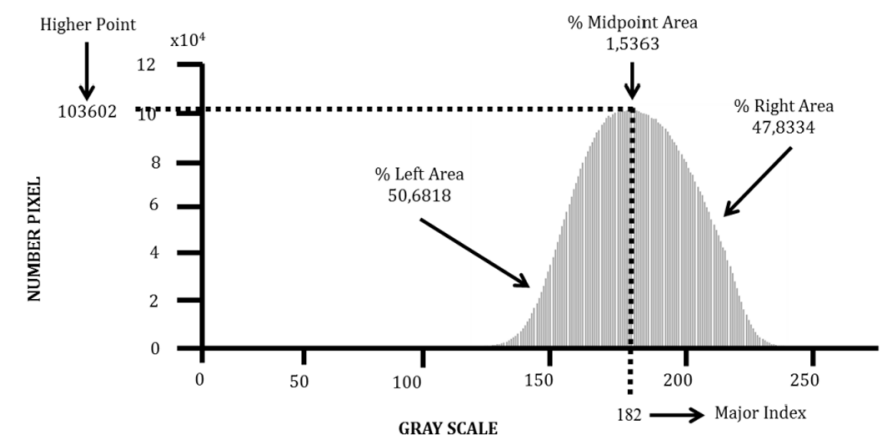

Fig.3. Values of the LA, RA, MP, HP and MI represented in one of the processing histograms of a photomicrography corresponding to one section of the thymic lobe. - Software Matlab ${ }^{\circledR} 6.5$ - Mathworks.

Table 2. Distribution of the thymic lobes and birds among the 5 optical categories of scores related with the lymphocytary depletion

\begin{tabular}{ccc}
\hline Optical Score & Number of lobes $(\%)$ & Number of poultries $(\%)^{*}$ \\
\hline 1 & $42(10.45)$ & $9(14)$ \\
2 & $121(30.10)$ & $21(31)$ \\
3 & $127(31.60)$ & $21(31)$ \\
4 & $70(17.41)$ & $9(14)$ \\
5 & $42(10.44)$ & $7(10)$ \\
TOTAL & $402(100)$ & $67(100)$
\end{tabular}

*Optical score obtained from the reading mode of the six thymic lobes by bird.

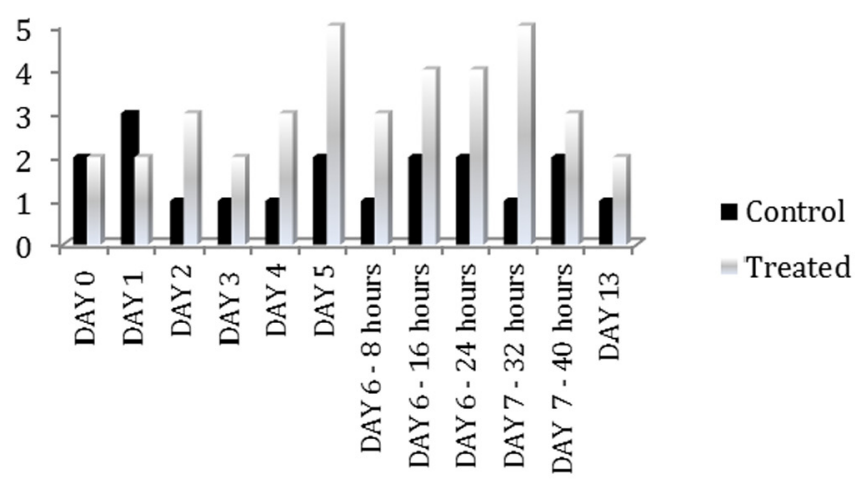

Fig.4. OS of the thymus throughout at the 13 days of the lobe sampling.

Table 3. Results of the DS classifications related to the lymphocytary depletion of the thymus per bird given by the ANNs

\begin{tabular}{lccccccc}
\hline & OE 1 & OE 2 & OE 3 & OE 4 & OE 5 & Total & PPV (\%) \\
\hline DS 1 & 9 & 0 & 0 & 0 & 0 & 9 & 100 \\
DS 2 & 0 & 20 & 2 & 0 & 0 & 22 & 90,91 \\
DS 3 & 0 & 1 & 19 & 0 & 0 & 20 & 95 \\
DS 4 & 0 & 0 & 0 & 9 & 1 & 10 & 90 \\
DS 5 & 0 & 0 & 0 & 0 & 6 & 6 & 100 \\
Total & 9 & 21 & 21 & 9 & 7 & 67 & - \\
Sensitivity (\%) & 100 & 95.24 & 90.48 & 100 & 85.71 & - & - \\
Specificity (\%) & 100 & 95.65 & 97.83 & 98.28 & 100 & - & -
\end{tabular}

\section{DISCUSSION}

It was found that the use of glucocorticoid based on the protocol of treatment developed by Kong et al. (2002) was well succeeded. So Thymus with different degree of lym- phocytary depletion were obtained. The use of this drug to damage the lymphoid tissue directly was also proposed by Hussar et al. (2011) in adult Wistar mice. The authors reported that, with the interruption of the treatment during one week, there was thymus recovery regarding the lymphocytary structure.

These findings agree with the ones of this work, where the organ was considerably affected by the treatment being partially recovered after one week of the end of the drug administration. According to Kong et al. (2002), this drug does not affect the survival and the overall health of the birds. It just causes growth delay. However, it is important to highlight that due to that fact of being an immune depressor agent, it can increase the risk of infections.

According to Isobe \& Lillehoj (1993), the administration of this drug has several advantages such as: easy administration, low cost, no suffering of the birds during the inoculation and it does not cause depletion of the humural and cellular immunity. Besides, it does not demand an experimental environment with high level of biosafety because infectious or dangerous agents for the public health are not used (virus, bacteria and fungus).

The ANN developed presented good performance considering that the accuracy percentage was $94,03 \%$. Such result is shown by the values of sensitivity and specificity which were higher than $90 \%$ for most scores. Despite the high percentage of correct classifications, it is important to highlight that it is always possible to improve the ANN by adding the analyses of other histologists. Moraes et al. (2010), had the accuracy percentage of approximately $62 \%$ while classifying the follicles of cloacal bursa using also, the ADDL system in five scores. This fact shows how adjusted the model built in this study to evaluate the thymus is.

It also observed that even when the DS differs from the OS, this difference gave us scores next to the correct one, showing the high level of adjustment obtained and the almost non-existence classificatory difficulty of the ANN. This finding was not observed by Moraes et al. (2010), who noticed a gray zone for the classification of the follicles of cloacal bursa in the DS 2, 3 and 5 .

Salle et al. (2011) performed a study in order to validate the ADDL system for the cloacal bursa. It was done from the evaluation of lymphocytary depletion, comparing the evaluation of three histologists with different experience level, and from the ADDL system which was carried out by three different operators. The results found had significant difference among the evaluation of all histologists as well as the two evaluations accomplished by the same histologist. Significant difference was not observed while analyzing the lymphoid depletion by the ADDL system, considering the distinct operators. The authors understand that this new methodology is not influenced by the person who performs it. It is only necessary appropriate training for doing so. Together with the obtained data on this study, this fact shows that the methodology used to level the lymphocytary depletion in the thymus is absolutely suitable for the laboratory routine and research.

As advantages of this technique we have the reproducibility and the precise knowledge of the classificatory 
mistake. The classificatory mistakes are not measurable in the conventional histological methods. Despite the advantages, the authors emphasized that this is not a technique for diagnosis. So, it does not replace the role of the histopathologist. Concerning the immunological condition of the animals, this system is useful for tutoring, turning possible the scientific comparison of the results through continuous tutoring in different periods.

Floyd (2011), comparing microscopic methods for the histopathological evaluation of cloacal bursa found important differences in the classification per scores in the same sample. It shows how subjective the conventional methodologies are to determine degrees of injuries.

Studies on the evaluation of the thymus usually need more detailed methodological description concerning the number of evaluated lobes. This work also proved that there are varied degrees of depletion among the lobes. Due to the probability of under or super estimate the thymus regarding the degrees of lymphocytary, the histological evaluation of this organ should not be accomplished considering just one lobe when it is the main objective.

\section{CONCLUSIONS}

The results of this study complement the work performed by Moraes et al. (2010), because the thymus plays a relevant role in the cellular immunity.

It was possible to show that an evaluation of the immune system of broiler, is perfectly applicable when objective criteria are adopted for the histological analyses, reducing the subjectivity.

This could be done using tools of image analyses together with the ANNs.

\section{REFERENCES}

Floyd W.D. 2011. Bursa morphometrics (comparison of microscopic methods for bursa histopathology evaluation). 62nd Annual Meeting of the American College of Veterinary Pathologists and 46th Annual Meeting of the American Society for Veterinary Clinical Pathology, Nashville, Tennessee, p.15-17. (Abstract)
Hadipour M.M., Farjadian S.H., Azad F., Sheibani N. \& Olyaie A. 2011. Histologic lesions of thymus and bursa of Fabricius in commercial broiler chickens inoculated with H9N2 avian influenza virus. Int. J. Anim. Veter. Adv. 3:186-188.

Hussain I., Mahmood M.S. \& Arshad M.I. 2012. Immune system dysfunction in broiler chickens experimentally inoculated with fowl adenovirus serotype-4 associated with inclusion body hepatitis hydropericardium syndrome. Turk. J. Vet. Anim. Sci. 36:223-230.

Hussar P., Tokin I., Filimonova G., Tokin I. \& Hussar U. 2011. Dexamethasone induced T lymphocyte apoptosis in different lymphoid organs. Papers on Anthropology 20:117-127.

Isobe T. \& Lillehoj H.S. 1993. Dexamethasone suppresses T cell-mediated immunity and enhances diseases suceptibility to Eimeria mivati infection. Vet. Immunol. Immunop. 39:431-445.

Kong F.K., Chen C.H. \& Cooper M.D. 2002. Reversible disruption of thymic funcition by steroid treatment. J. Immunol. 168:6500-6505.

Luna P.G. 1968. Manual of Histologic Staing Methods of the Armed Forces Institute of Pathology. 13rd ed. McGraw-Hill, New York. 258p.

Moraes L.B., Osório F.S., Salle F.O., Souza G.F., Moraes H.L.S., Fallavena L.C.B., Santos L.R. \& Salle C.T.P. 2010. Evaluation of follicular lymphoid depletion in the Bursa of Fabricius: An alternative methodology using digital image analysis and artificial neural networks. Pesq. Vet. Bras. 30:340-344.

Salle C.T., Moraes L.B., Zimermmam F.C., Fallavena L.C.B., Osório F.S., Salle F.O. \& Moraes H.L.S. 2011. Comparative avaluation of lymphoid depletion of bursa of fabricius using the ADDL system and the conventional subjective method. Proc. 60th Western Poultry Disease Conference, Sacramento, CA, p.130-131. (Abstract)

Sharma J.M., Dohms J., Walser M. \& Synder D.B. 1993. Presence of lesions without virus replication in the thymus of chicken exposed to infections bursal disease virus. Avian Dis. 37:741-748.

Smyth A.J., Moffett D.A., Connor T.J. \& McNulty M.S. 2009. Chicken anaemia virus inoculated by the oral route causes lymphocyte depletion in the thymus in 3-week-old and 6-week-old chickens. Avian Pathol. 35:254-259.

Toro H., Van Santen V.L., Hoerr F.J. \& Breedlove C. 2009. Effects of chicken anemia virus and infectious bursal disease virus in commercial chickens. Avian Dis. 53:94-102.

Tranquilim M.V., Botelho G.G.K., Bortolini Z., Lehmkuhl R.C. \& Lang R.R. 2007. Osteossíntese de úmero em Ramphastos dicolorus (tucano de bico verde): relato de caso. Ambiência 3:261-266.

Van Santen V.L., Joiner K.S., Murray C., Petrenko N.Hoerr F.J. \& Toro H. 2004. Pathogenesis of chicken anemia virus: comparation of the oral and intramuscular routes of infection. Avian Dis. 48:494-504. 